\title{
Aikuiskasvatustieteen tulevaisuuden teesit
}

\begin{abstract}
1
Työelämän keskiössä ovat tulevaisuudessa ihmiset, ja juuri ihmistuntemuksessa aikuiskasvattajat ovat edelläkävijöitä. Aikuiskasvatuksen opiskelijat Susanna Tuominen ja Sharon Laine laativat tieteenalansa tulevaisuuden teesit.
\end{abstract}

\section{T Aikuiskasvatustieteilijä ON DIALOGIN ASIANTUNTIJA.}

Yhä verkostoituneemmassa maailmassa tarvitaan kykyä yhteistyöhön ja dialogiin. Me kasvatustieteilijät näemme kasvun koko elämän laajuisena ja mittaisena prosessina. Osamme kohdata ihmisiä tavalla, josta välittyy ymmärrys ihmisen asemaan muutoksen, oppimisen ja yhteistyön keskellä. Me aikuiskasvatustieteilijät olemme ratkaisukeskeisiä ja muutoksen kanssa yhteistyötä tekeviä asiantuntijoita. Työelämän vaatima ketteryys ja joustavuus näkyvät monimuotoisena ja hajautettuna asiantuntijuutena.

Työllistymisen tutkijat Emily Beaumont, Sharon Gedye ja Samantha Richardson (2016) siteeraavat milleniaalien ajatuksia tulevaisuuden työllistymisestä. Epävarmuus lisääntyy, ja huoli omasta osaamisesta sekä kyvystä pysyä mukana kehityksessä on suuri. Digitalisaation muokkaamat koulutus- ja työskentelymahdollisuudet vaativat omanlaistaan asiantuntijuutta (Beaumont ym. 2016, 3).

Robotisaatioaktivisti Cristina Anderssonin (2018) mukaan työntekijältä vaaditaan yhä joustavampaa rea- gointia ja monikanavaisuuden hallintaa. Uuden oppimisen ja uusien toimintamallien hyväksyminen vie aikaa ja vaatii niin ulkoista kuin sisäistä motivaatiota. Digitalisaation herättämiä huolenaiheita ovat yhteisöjen kyky sopeutua ja toimia muutoksessa, työn vaatimusten muuttuminen, epävarmuus ja tutkintojen monimuotoistumisen tarve (Andersson 2018, 22-24).

\section{AikUiskasvatustieteilijä ON MUUTOKSEN ASIANTUNTIJA.}

Kyky sopeutua työelämän muutokseen ja olla askeleen edellä välineiden ja toimintamallien käytössä ovat aikuiskasvattajalle tarpeen.

Yhteiskunnallisten muutosten tutkija Christophe Degryse (2016) sanoo, että ihminen pyrkii aktiivisella toimijuudella sopeutumaan digitalisaation tuomiin paineisiin ja muutoksiin. Työelämän ja oppimisen näkökulmasta tarvitaan uusia välineitä, kuten jatkuvaa tukea organisaatioihin, tukemaan muutosta (Degryse 2016, 5-9).

Tietokirjailija Jonathan Weiner (1970,33) viittaa Charles Darwinin evoluutioteorian (1859) huomi- 


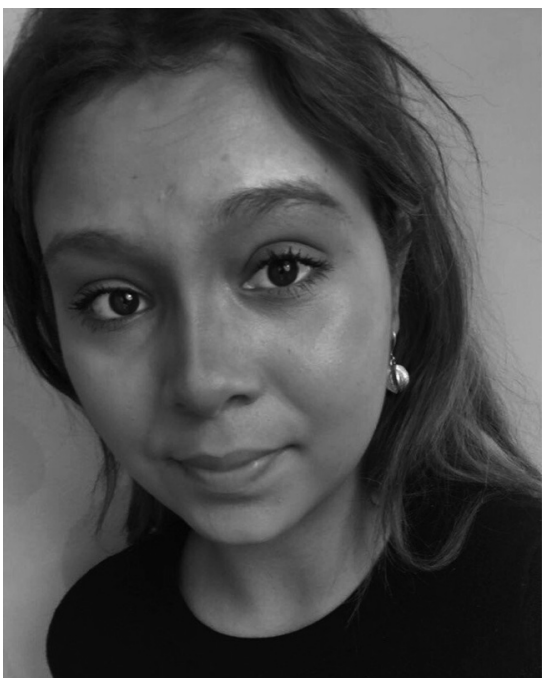

\section{Sharon Laine}

opiskelija

yleinen ja aikuiskasvatustiede

Helsingin yliopisto

"Opiskelen aikuiskasvatustiedettä, sillä tahdon olla vapaa ja luova. Haluan pystyä tyydyttämään tiedonjanoani yliopistolla monitieteisesti. Haluan olla mukana luomassa tulevaisuutta enkä vain seistä vieressä katsomassa sen rakentumista."

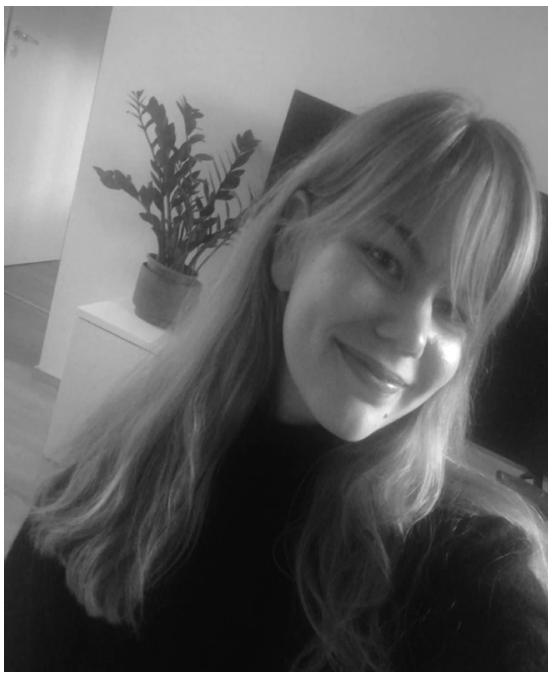

\section{Susanna Tuominen}

opiskelija

aikuiskasvatustiede

Turun yliopisto

"Haluan työskennellä nimenomaan ihmisten parissa, mutta haluan edelleen etsiä sitä omaa juttuani, tunnustella ja mutustella rauhassa." oon sopeutumisesta lajien säilymisen edellytyksenä. Digitalisaatioon sopeutuminen on sitä, että mobiililaite on kasvanut kiinni käteemme, ja kasvokkaiset kontaktit ovat vähentyneet. Viestinnän ja johtamisen tutkijat Gerardine DeSanctis ja Peter Monge (1998) toteavat, että etätyö on tullut jäädäkseen, ja näin säästyvät tilavuokrat päätyvät yhtiöiden kasvun vahvistamiseen ja tuottavuuden tehostamiseen. Teknologiset toimintamallit syövät yhä suuremman osan organisaatiosta kokonaisuutena (DeSanctis \& Monge 1998).

Professori Sami Paavola (2020) puhuu augmentationismista, jolla hän viittaa ihmisen ja koneen väliseen vuorovaikutukseen. Aikuiskasvatustieteilijä pystyy kokonaisvaltaisella ihmisen oppimisen ja vuorovaikutuksen ymmärryksellä löytämään ympäristölle ja ihmiselle optimaaliset vaihtoehdot.
3

AIKUISKASVATUSTIETEILIJÄLLÄ

ON LAAJA NÄKÖKULMA.

Opinnoissamme kehitämme osaamistamme kohti laajaa ja monipuolista asiantuntijuutta, johon kuuluvat niin teknologisessa kehityksessä mukana muovautuminen kuin työelämän murroksen ymmärtäminen. Opintojen vahvuus on poikkitieteellisyys, sillä eri tieteenalojen tutkimus, ajatusmaailmat ja näkökulmat laventavat ymmärrystä maailmasta.

Kasvatustieteilijät ymmärtävät ja jakavat kiinnostuksen jatkuvaan oppimiseen. Samalla kun pyrimme ulkoistamaan osaamistamme muille, meidän tulee kehittää omaa osaamistamme integroimalla elinikäinen oppiminen omaan tekemiseemme. Meillä on kehittäjinä vastuu ja velvollisuus ylläpitää omaa osaamistamme tulevaisuuden tarpeisiin. 
RATKAISUKESKEISYYS MOTIVOI

JA EDIST $\ddot{A}$ AINA VAIN

PAREMPIIN TOIMINTATAPOIHIN

NIIN KOULUTUKSESSA KUIN

TYÖEL ̈̈MÄSS̈̈.

\section{Aikuiskasvatustieteilijä Pyrkil
Ratkaisuihin.}

Kasvatustieteen emeritusprofessori James Bosco (2007) sanoo, että tietomme ihmisen kyvystä elinikäiseen oppimiseen ja halumme kehittää yhteisöjen toimivuutta ovat tarpeen tulevaisuudessa. Viestintävälineet muuttuvat, mutta ihmisen ohjaaminen, opettaminen ja kehittäminen eivät käy tarpeettomiksi. Tulevaisuuden aikuiskasvatustieteilijä luo ja kehittää toimivia yhteisöjä (Bosco 2007, 45).

Ratkaisukeskeisyys motivoi ja edistää aina vain parempiin toimintatapoihin niin koulutuksessa kuin työelämässä. Tulevaisuuden tutkijat Leena Jokinen ja Riikka Saarimaa (2020) toteavat, että IT-palveluiden merkitys ja työn murrosten radikalisoituminen ovat postmodernita seuraavan ajanjakson ja tulevien sukupolvien trendejä (Jokinen \& Saarimaa 2020, 82).

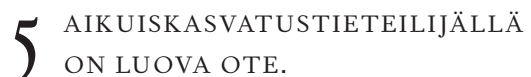

Luovat ja poikkeavat toimintamallit vahvistavat aikuiskasvatustieteilijän asiantuntija-asemaa.

Johtamisen tutkija Sari Salojärvi (2018) kirjoittaa digitalisaation haasteista henkilöstöjohtamisen näkökulmasta. Samalla kun organisaatiot kehittävät digitaalista toimintaansa, työntekijät kantavat huolta työpaikoistaan etenkin automatisaation vahvistuessa. Digitalisaatio ja tekoäly luovat kuitenkin uusiakin työpaikkoja, joissa uutta tietoa voidaan soveltaa vanhaan ja toisin päin (Salojärvi 2018, 16; Andersson 2018, 22-24).

Digitalisaatio muuttaa työelämää kokonaisvaltaisesti. Sen avulla kehitetään työtapoja ja tehokkuutta, mutta syntyy myös uusia ja markkinoita ja palveluita. Tekoäly vaikuttaa niin osaamisvaatimuksiin kuin oppimiseen (Koski \& Husso 2018). Aikuiskasvatustieteilijän asiantuntijuudelle on kysyntää, sillä tulevaisuudessa tarvitaan erityisesti oppimisen ja osaamisen kehityksen asiantuntijoita, jotta ihmiset sopeutuvat työelämän muutoksiin (Salojärvi 2018,14-16).

\section{LÄHTEET}

Andersson, C. (2018). Työllä on tulevaisuus - kuka on tekijä? Työn tuuli, 1/2019, 20-24.

Beaumont, E., Gedye, S. \& Richardson, S. (2016). 'Am I employable?' Understanding students' employability confidence and their perceived barriers to gaining employment. Journal of Hospitality, Leisure, Sport \& Tourism Education, 19, 1-9.

Bosco, J. (2007). Lifelong learning. What? Why? How? Western Michigan University, 8. Leningrad State University.

Degryse, C. (2016). Digitalisation of the economy and its impact on labour markets. ETUI. https://www.etui. org/publications/working-papers/digitalisation-of-theeconomy-and-its-impact-on-labour-markets

DeSanctis, G., \& Monge, P. (1998). Communication processes for virtual organizations. Journal of Computer-Mediated Communication, 3(4). https://doi. org/10.1111/j.1083-6101.1998.tb00083.x
Jokinen, L., \& Saarimaa, R. (2020). Osaamisen ennakointia ja tulevaisuuden osaamistarpeita. Teoksessa S. Mahlamäki-Kultanen, T. Hämäläinen, P. Pohjonen \& K. Nyyssölä (toim.) Maailman osaavin kansa 2020. Koulutuspolitiikan keinot, mahdollisuudet ja päämäärät. Koulutustutkimusfoorumi, Opetushallitus, 68-81.

Salojärvi, S. (2018). Digitalisaatio haastaa henkilöstöjohtamisen-HR: n näytönpaikka. Työn tuuli 1/2018, 8-19.

Koski, O. \& Husso, K. (2018). Tekoälyajan työ: neljä näkökulmaa talousteen, työllisyyteen, osaamiseen ja etiikkaan. Työ- ja elinkeinoministeriön julkaisuja. Helsinki: Työ- ja elinkeinoministeriö, 35-42. 